\author{
Beata Krakowiak \\ Uniwersytet Łódzki \\ Katedra Geografii Miast i Turyzmu \\ 90-142 Łódź, ul. Kopcińskiego 31 \\ tel. 048426354556 \\ agakrak@geo.uni.lodz.pl
}

\section{DZIEDZICTWO KULTUROWE ZAKONU KAMEDUEÓW NA ZIEMIACH POLSKICH}

\section{WPROWADZENIE}

Dziedzictwo kulturowe to termin powszechnie znany i używany. Przegląd różnych definicji poZwala ustalić, że pod pojęciem tym kryje się spuścizna, zarówno o charakterze materialnym, jak i niematerialnym (duchowym), pozostawiona po przodkach dla następnych pokoleń, cenna z uwagi na wartości historyczne, patriotyczne, religijne, artystyczne i in. Dziedzictwo to ma znaczenie dla tożsamości i ciągłości rozwoju spolecznego, kulturalnego (...), kultywowania piękna i wspólnoty cyWilizacyjnej (PRUSZYŃSKı 2004). W zależności od przyjętej skali można mówić o dziedzictwie ludzkości, dziedzictwie narodowym czy dziedzictwie określonej spoleczności. Celem niniejszego opracowania jest pokazanie dziedzictwa zakonu kamedułów w Polsce.

\section{OKOLICZNOŚCI POWSTANIA ZAKONU}

Zakon kamedułów powstał z inicjatywy św. Romualda $\mathrm{z}$ Rawenny pod koniec X w. Do powolania Wspólnoty doszło na obszarze Włoch, niedaleko miejscowości Arezzo w Toskanii. Pierwotne Campo di Maldoli, czyli niewielki fragment ziemi ofiarowany braciom przez rodzinę Maldolich, dał późniejszą nazwę miejscowości - Camaldoli, oraz nazwę zakonu - kameduli (w wersji spolszczonej). Przedstawiciele wspólnoty kierowali się w swoim życiu zakonnym regułą św. Benedykta. Zgodnie

\section{THE CULTURAL HERITAGE OF THE CAMELDOLITE ORDER IN POLAND}

\section{INTRODUCTION}

Cultural heritage is a common term. A review of different definitions shows that the term describes the material and nonmaterial (spiritual) legacy, left by ancestors to future generations. It is precious due to its historical, patriotic, religious, artistic and other values. This heritage is important for the identity and continuity of social and cultural development (...), cultivating the beautiful and what is common between cultures (PRUSZYŃSKI 2004). Depending on the scale assumed, we can talk about the heritage of humanity, national heritage or of a given community. The aim of this article is to present the heritage of the Cameldolite order in Poland.

\section{THE ORIGINS OF THE CAMELDOLITE ORDER}

The Cameldolite Order was created by St Romuald of Ravenna at the end of the $10^{\text {th }}$ c., in Italy, not far from Arezzo in Tuscany. The original Campo di Maldoli, i.e. a small piece of land offered to the brethren by the Maldoli family, gave its name to the town of Camaldoli, and to the order - the Cameldolites. The brethren were guided by $\mathrm{St}$ Benedict's rule. They searched for God 
$\mathrm{z}$ nią poszukiwali Boga przez modlitwę, naukę i pracę, realizując hasło „ora et labora” (módl się i pracuj). Motywem powolania wspólnoty była chęć naprawy życia religijnego, co znalazło potwierdzenie w ślubie składanym przez członków zakonu, dotyczącym poprawy obyczajów. W roku 1524 za sprawą Pawła Justinianiego doszlo do rozłamu w obrębie zakonu i powołania kongregacji Zgromadzenia Pustelników Kamedulów Góry Koronnej (Congregatio Eremitarum Camaldulensium Montis Coronae), opowiadających się za bardziej surowym przestrzeganiem zasad życia ustalonych przez patrona wspólnoty - św. Romualda.

\section{KAMEDULI W POLSCE}

Do Polski uczniowie św. Romualda dotarli prawdopodobnie w XI w., aczkolwiek brak jest materialnych śladów ich obecności $\mathrm{z}$ tego okresu. Przypuszczenia takie wysnuto na podstawie legendy opowiadającej o męczeńskiej śmierci braci kamedułów, poniesionej z rąk przypadkowych rabusiów. W rzeczywistości pierwsze założenia klasztorne Zgromadzenia Pustelników Kamedułów Góry Koronnej w Polsce powstały w XVII w., a ich pojawienie się było wynikiem zwiększonego zainteresowania życiem religijnym.

Najstarszy klasztor kamedulski w Polsce ufundowano w krakowskich Bielanach w 1604 r. W dalszej kolejności powstały założenia w Rytwianach oraz Bielanach warszawskich (tab. I). Większość polskich założeń pochodzi z XVII w., ale pamiętać należy, że okres budowy obiektów trwał czasami wiele lat. Powstające klasztory wpisywały się w istniejąca już wtedy w Polsce grupę klasztorów benedyktyńskich, cysterskich, franciszkańskich, dominikańskich $i$ in.

Inicjatorami i fundatorami polskich klasztorów kamedulskich byli królowie (Bielany warszawskie, Wigry) oraz osoby prywatne, piastujące wysokie stanowiska państwowe, które w ten sposób deklarowały i potwierdzały swoją wiarę (tab. I). Tylko w jednym przypadku powstanie klasztoru było efektem działań samych kamedułów. Fakt ten wynikal ze wspomnianej wcześniej legendy mówiącej o zamordowaniu zakonników. Dla uczczenia tego wydarzenia, w miejscu rzekomej śmierci braci, ich następcy wybudowali pustelnię (Bieniszew).

Na obszarze ówczesnej Polski powstało w sumie tylko osiem klasztorów kamedulskich - w Bielanach krakowskich, Bieniszewie, Bielanach warszawskich, Milatynie, Pożajściu, Rytwianach, Szańcu through prayer, study and work, following the motto 'ora et labora' (pray and work). The motive behind setting up the community was a willingness to improve religious life, reflected in the vows taken by the order's members regarding moral development. In 1524, at the instigation of Paul Justiniani, there was dissension within the order and the Congregatio Eremitarum Camaldulensium Montis Coronae (Congregation of Cameldlite Hermits at Monte Corona) was established proclaiming a more severe set of rules than those established originally by St Romuald.

\section{CAMELDOLITES IN POLAND}

It is believed that St Romuald's followers arrived in Poland in the $11^{\text {th }} \mathrm{c}$., but there is no material evidence to prove it. The belief is based on a legend about the horrible death of some Cameldolite brethren at the hands of robbers. In fact the first monasteries of the Congregation of Cameldolite Hermits at Monte Corona in Poland appeared in the $17^{\text {th }}$ c., as a result of a growing interest in religious life.

The oldest Polish Cameldolite monastery was built in Bielany (Kraków) in 1604 with Rytwiany and Bielany (Warsaw) following (table I). Most Polish monasteries come from the $17^{\text {th }} \mathrm{c}$. But it should be remembered that sometimes the act of building lasted many years. The new monasteries joined Benedictine, Cistercian, Franciscan, Dominican and other monasteries already existing in Poland.

The founders of Polish Cameldolite monasteries were kings - Bielany (Warsaw) and Wigry - and by those holding high offices of state who declared and confirmed their faith in this way (table I). Only in one case was a monastery the result of the Cameldolites' own efforts and this was due to the legend mentioned above. To commemorate that event, at the site of the alleged death of the brothers, their successors built a hermitage (Bieniszew).

At that time there were only eight Cameldolite monasteries in Poland - in Bielany (Kraków), Bieniszew, Bielany (Warsaw), Milatyn, Pożejście, Rytwiany, Szaniec 
T a b e I a I. Charakterystyka założeń klasztornych zakonu kamedułów w Polsce

\begin{tabular}{|c|c|c|c|c|c|c|c|c|}
\hline Miejscowość & $\begin{array}{l}\text { Bielany- } \\
\text { Kraków }\end{array}$ & $\begin{array}{l}\text { Bielany - } \\
\text { Warszawa }\end{array}$ & $\begin{array}{l}\text { Bieniszew } \\
\text { k. Konina }\end{array}$ & $\begin{array}{l}\text { Rytwiany } \\
\text { k. Staszowa }\end{array}$ & $\begin{array}{c}\text { Szaniec } \\
\text { k. Buska Zdroju }\end{array}$ & $\begin{array}{l}\text { Wigry } \\
\text { k. Suwałk }\end{array}$ & $\begin{array}{l}\text { Milatyn* } \\
\text { k. Lwowa }\end{array}$ & $\begin{array}{l}\text { Pożajście* } \\
\text { k. Kowna }\end{array}$ \\
\hline $\begin{array}{l}\text { Nazwa } \\
\text { Wtasna }\end{array}$ & $\begin{array}{c}\begin{array}{c}\text { Erem Srebrnej } \\
\text { Góry }\end{array} \\
\end{array}$ & $\begin{array}{l}\text { Erem Góry } \\
\text { Królewskiej }\end{array}$ & $\begin{array}{l}\text { Erem Pięciu } \\
\text { Braci } \\
\text { Męczenników }\end{array}$ & $\begin{array}{c}\text { Pustelnia } \\
\text { Zlotego Lasu }\end{array}$ & $\begin{array}{c}\text { Erem } \\
\text { Margrabski }\end{array}$ & $\begin{array}{l}\text { Erem W } \\
\text { Wigiers }\end{array}$ & $\begin{array}{l}\text { Erem św. } \\
\text { Krzyża }\end{array}$ & $\begin{array}{l}\text { Erem Góry } \\
\text { Pokoju }\end{array}$ \\
\hline Położenie & $\begin{array}{c}\text { Wzniesienie, } \\
\text { las }\end{array}$ & Las & $\begin{array}{c}\text { Las, } \\
\text { wzniesienie }\end{array}$ & Las & Wzr & $\begin{array}{l}\text { Wzniesienie, } \\
\text { brzeg jeziora }\end{array}$ & Brak & nie \\
\hline Rok fundacji & $1604 \mathrm{r}$. & $1641 \mathrm{r}$. & $1663 \mathrm{r}$. & $1621 \mathrm{r}$. & $1722 \mathrm{r}$. & $1667 \mathrm{r}$. & $1738 \mathrm{r}$. & $1667 \mathrm{r}$. \\
\hline $\begin{array}{l}\text { Inicjator/ } \\
\text { fundator } \\
\text { założenia }\end{array}$ & $\begin{array}{c}\text { Mikołaj Wolski, } \\
\text { marszałek } \\
\text { wielki koronny }\end{array}$ & $\begin{array}{c}\text { Król } \\
\text { Whadysław IV }\end{array}$ & $\begin{array}{l}\text { Zakonnicy ka- } \\
\text { meduli, Albert } \\
\text { Kadzidłowski, } \\
\text { starosta } \\
\text { radziejowski }\end{array}$ & $\begin{array}{c}\text { Jan Tęczyński, } \\
\text { wojewoda } \\
\text { krakowski }\end{array}$ & $\begin{array}{c}\text { Józef } \\
\text { Myszkowski, } \\
\text { kasztelan } \\
\text { sandomierski }\end{array}$ & $\begin{array}{c}\text { Król } \\
\text { Jan Kazimierz }\end{array}$ & $\begin{array}{c}\text { Teresa } \\
\text { z Karśnickich }\end{array}$ & $\begin{array}{l}\text { Krzysztof Pac, } \\
\text { kanclerz } \\
\text { litewski }\end{array}$ \\
\hline Wezwanie & \begin{tabular}{|c|} 
Pw. \\
Wniebowzięcia \\
NMP
\end{tabular} & $\begin{array}{c}\text { PW. } \\
\text { Niepokalanego } \\
\text { Poczęcia NMP }\end{array}$ & $\begin{array}{c}\text { PW. } \\
\text { Ofiarowania } \\
\text { NMP }\end{array}$ & $\begin{array}{c}\text { Pw. } \\
\text { Zwiastowania } \\
\text { NMP }\end{array}$ & $\begin{array}{c}\text { Pw. } \\
\text { sw. Józefa }\end{array}$ & $\begin{array}{l}\text { Pw. Niepoka- } \\
\text { lanego Po- } \\
\text { częcia NMP } \\
\end{array}$ & Brak danych & $\begin{array}{c}\text { Pw. } \\
\text { Nawiedzenia } \\
\text { NMP }\end{array}$ \\
\hline $\begin{array}{l}\text { Obecne } \\
\text { wykorzy- } \\
\text { stanie } \\
\text { obiektu }\end{array}$ & $\begin{array}{c}\text { Klasztor } \\
\text { oo. } \\
\text { kamedułów }\end{array}$ & $\begin{array}{c}\text { Kościót, } \\
\text { Uniwersytet } \\
\text { Stefana } \\
\text { Wyszyńskiego }\end{array}$ & $\begin{array}{l}\text { Klasztor } \\
\text { oo. } \\
\text { kamedułów }\end{array}$ & $\begin{array}{l}\text { Kosciól diece- } \\
\text { zjalny, Ośrodek } \\
\text { Kultury i Edu- } \\
\text { kacji „Zródło” }\end{array}$ & $\begin{array}{l}\text { Obiekt nie za- } \\
\text { chował się, z wy- } \\
\text { jatkiem drewnia- } \\
\text { nej kapliczki }\end{array}$ & $\begin{array}{l}\text { Kościół, } \\
\text { Dom Pracy } \\
\text { Twórczej }\end{array}$ & $\begin{array}{c}\text { Obiekt nie } \\
\text { zachował się }\end{array}$ & $\begin{array}{c}\text { Zakon Sióstr } \\
\text { Kongregacji } \\
\text { sw. } \\
\text { Kazimierza }\end{array}$ \\
\hline
\end{tabular}

"Obiekt poza granicami Polski.

Żródło: FLORKOWSCY 2005, badania własne.

i Wigrach (tab. I, rys. 1). Dwie z wymienionych miejscowości - Milatyn i Pożejście - znajdują się obecnie poza granicami naszego kraju ( $\mathrm{z}$ tego też powodu nie będą podlegać dalszej analizie). Wybór miejscowości nie wynikał ze świadomej polityki zakonu, lecz wiązal się z osobą fundatora, który przekazywał na własność zakonników ustaloną część swoich ziem. Kapitula generalna zakonu decydowała natomiast o ostatecznym miejscu budowy klasztoru. and Wigry (table I, fig. 1). Two of these Milatyn and Pożejście - are currently outside Polish borders (and so are excluded from further analysis here). The choice of location was not the result of a conscious policy of the order, but depended on the founders who passed parts of their land to the monks. However, the General Chapter of the order decided where the actual building site was to be.

T a b | e I. Description of Cameldolite monasteries in Poland

\begin{tabular}{|c|c|c|c|c|c|c|c|c|}
\hline Destination & $\begin{array}{l}\text { Bielany- } \\
\text { Kraków }\end{array}$ & $\begin{array}{l}\text { Bielany- } \\
\text { Warsaw }\end{array}$ & $\begin{array}{l}\text { Bieniszew } \\
\text { near Konin }\end{array}$ & $\begin{array}{c}\text { Rytwiany } \\
\text { near Staszów }\end{array}$ & $\begin{array}{l}\text { Szaniec near } \\
\text { Busko Zdrój }\end{array}$ & $\begin{array}{l}\text { Wigry near } \\
\text { Suwałki }\end{array}$ & $\begin{array}{c}\text { Milatyn } \\
\text { near Lvov }\end{array}$ & $\begin{array}{l}\text { Pożajście * } \\
\text { near Kaunas }\end{array}$ \\
\hline Name & $\begin{array}{c}\text { Srebrnej } \\
\text { Góry } \\
\text { hermitage }\end{array}$ & $\begin{array}{c}\text { Góry } \\
\text { Królewskiej } \\
\text { hermitage }\end{array}$ & $\begin{array}{c}\text { Pięciu Braci } \\
\text { Męczenników } \\
\text { hermitage }\end{array}$ & $\begin{array}{l}\text { Ztotego Lasu } \\
\text { hermitage }\end{array}$ & $\begin{array}{l}\text { Margrabski } \\
\text { hermitage }\end{array}$ & $\begin{array}{c}\text { Wyspy } \\
\text { Wigierskiej } \\
\text { hermitage }\end{array}$ & $\begin{array}{l}\text { św. Krzyża } \\
\text { hermitage }\end{array}$ & $\begin{array}{l}\text { Góry Pokoju } \\
\text { hermitage }\end{array}$ \\
\hline Location & $\begin{array}{c}\text { Forest and } \\
\text { hills }\end{array}$ & Forest & Forest and hills & Forest & Hills & $\begin{array}{l}\text { Hills and } \\
\text { lake shore }\end{array}$ & No data & Hills \\
\hline $\begin{array}{l}\text { Year of } \\
\text { foundation }\end{array}$ & 1604 & 1641 & 1663 & 1621 & 1722 & 1667 & 1738 & 1667 \\
\hline Founder & $\begin{array}{l}\text { Mikołaj } \\
\text { Wolski - } \\
\text { Marshal }\end{array}$ & $\begin{array}{c}\text { King } \\
\text { Władysław } \\
\text { IV }\end{array}$ & $\begin{array}{c}\text { Cameldolite monks } \\
\text { and Albert Kadzidłowski } \\
\text { - Starosta (district head) } \\
\text { of Radziejów }\end{array}$ & $\begin{array}{c}\text { Jan Teczyński, } \\
\text { Kraków - Wojewoda } \\
\text { (provincial governor) }\end{array}$ & $\begin{array}{c}\text { Józef } \\
\text { Myszkowski- } \\
\text { castellan of } \\
\text { Sandomierz }\end{array}$ & $\begin{array}{l}\text { King Jan } \\
\text { Kazimierz }\end{array}$ & $\begin{array}{c}\text { Teresa } \\
\text { Karśnicka }\end{array}$ & $\begin{array}{l}\text { Krzysztof Pac, } \\
\text { Chancellor of } \\
\text { Lithuania }\end{array}$ \\
\hline Dedication & $\begin{array}{l}\text { The } \\
\text { Assump- } \\
\text { tion of the } \\
\text { Virgin } \\
\text { Mary }\end{array}$ & $\begin{array}{c}\text { The Im- } \\
\text { maculate } \\
\text { Conception } \\
\text { of the Virgin } \\
\text { Mary }\end{array}$ & $\begin{array}{l}\text { The Presentation } \\
\text { of the Virgin Mary }\end{array}$ & $\begin{array}{c}\text { The Annunciation of } \\
\text { the Virgin Mary }\end{array}$ & St Joseph & $\begin{array}{c}\text { The } \\
\text { Immaculate } \\
\text { Conception } \\
\text { of the } \\
\text { Virgin Mary }\end{array}$ & No data & $\begin{array}{l}\text { The Visitation of } \\
\text { the Virgin Mary }\end{array}$ \\
\hline $\begin{array}{l}\text { Present } \\
\text { use }\end{array}$ & $\begin{array}{l}\text { Cameldo- } \\
\text { lite } \\
\text { monastery }\end{array}$ & $\begin{array}{l}\text { Church - } \\
\text { Stefan } \\
\text { Wyszynski } \\
\text { University }\end{array}$ & $\begin{array}{l}\text { Cameldolite } \\
\text { monastery }\end{array}$ & $\begin{array}{l}\text { Diocesan church - } \\
\text { Żródło Culture } \\
\text { and Education } \\
\text { Centre }\end{array}$ & $\begin{array}{l}\text { Did not survive } \\
\text { - other than } \\
\text { the wooden } \\
\text { chapel }\end{array}$ & $\begin{array}{l}\text { Church - } \\
\text { artists' and } \\
\text { writers' } \\
\text { retreat }\end{array}$ & $\begin{array}{c}\text { No longer } \\
\text { existing }\end{array}$ & $\begin{array}{c}\text { Convent of the } \\
\text { 'St Kazimierz } \\
\text { congregation of } \\
\text { sisters' }\end{array}$ \\
\hline
\end{tabular}

* Outside present Polish borders.

S o u r c e: FLORKOWSCY 2005, author's own research. 


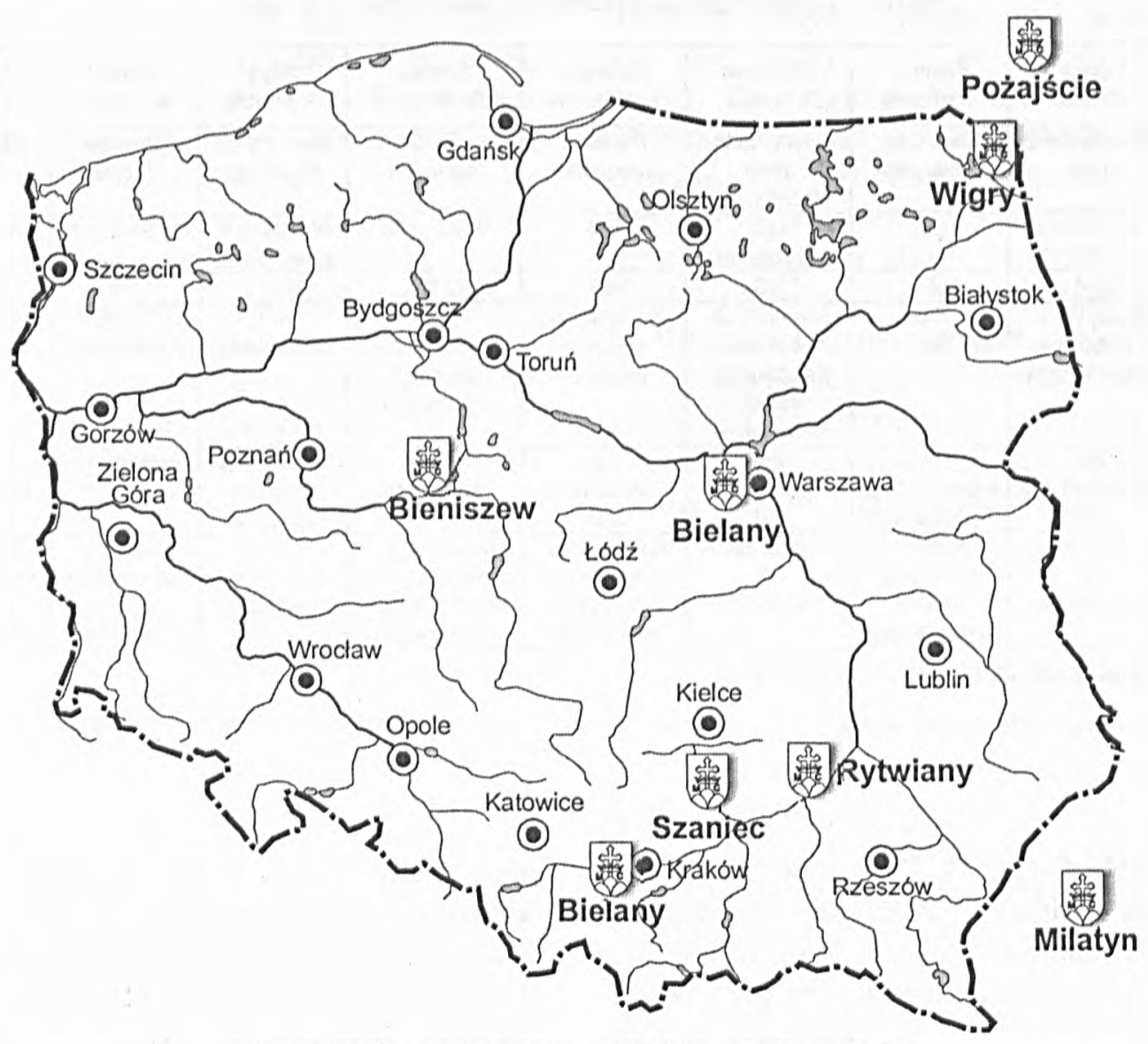

Rys. 1. Rozmieszczenie klasztorów kamedulskich na ziemiach polskich

(ż ró d ło: opracowanie własne na podstawie FLORKOWSKICH 2005)

Fig. 1. Distribution of Cameldolite monasteries in Poland (s o u r c e: author based on FLORKOWSCY 2005)

\section{SPECYFIKA ZAKONU}

\subsection{DUCHOWOŚĆ, WYGLADD MNICHA, OBYCZAJE}

Zakon kamedulów łączy w sobie dwie formy życia monastycznego - wspólnotową oraz pustelniczą. Głównym przesłaniem kamedułów jest hasło ,żyć sam na sam z Bogiem i żyć dla Boga”. Przejawem przyjętego hasła jest kontemplacja, możliwa dzięki odosobnieniu, przebywaniu w samotności, we wlasnym eremie-pustelni lub celi. Konsekwencją dobrowolnej izolacji jest milczenie. Zakonnicy żyjący w klasztorze spotykają się ze sobą jedynie w czasie modlitw, nabożeństw oraz ważnych wydarzeń religijnych; porozumiewają się ze sobą tylko $\mathrm{w}$ istotnych sprawach (LOZIŃSKI 2002). Ograniczenie kontaktów z drugą osobą dotyczy także tzw. świata zewnętrznego. Pustelnie kamedulskie dostępne są dla wiernych, a przede wszystkim dla kobiet tylko w ściśle określone dni

\section{DESCRIPTION OF THE ORDER}

\subsection{SPIRITUALITY, THE APPEARANCE OF THE MONKS AND CUSTOMS}

The Cameldolite order combines two forms of monastic life - living in a community and as a hermit. The most important Cameldolite rule is expressed in the saying: 'to face God and to live for God'. The rule can be followed through solitary contemplation and living alone in a cell and consequence of voluntary isolation is maintaining silence. The monks living in a monastery meet only during prayers, masses and important religious events; they communicate only about important matters (LOZIŃSKI 2002). These limitations also apply to contacts with the outside world. Cameldolite hermit cells are available to believers, but especially for women. 
w roku (12 dni). Zakonnicy prowadza bardzo ascetyczny tryb życia - ślubują ubóstwo indywidualne i wspólnotowe, realizują ustalone przez siebie posty. Wyrazem surowego życia jest także wygląd mnichów - dlugie brody, wygolone glowy. Na co dzień zakonnicy chodzą ubrani w białe tuniki, na które zakładają biały szkaplerz z kapturem (długą kamizelę).

W zakonie obowiązuje kult Maryi, co na obszarze Polski znajduje wyraz w wezwaniach kościołów kamedulskich. W opisywanej grupie obiektów większość poświęcona byla Najświętszej Maryi Pannie (tab. I). Fakt ten ma także związek z tym, że kult ten był powszechny w XVII-wiecznej Polsce. Popularnym zawołaniem kamedulów jest hasło memento mori - pamiętaj o śmierci. Do wydarzenia tego zakonnicy przygotowują się przez wszystkie lata swojego zakonnego życia. Po śmierci członkowie wspólnoty chowani są w obrębie klasztoru, w katakumbach.

Spośród omawianych polskich klasztorów dwa - Bielany krakowskie i Bieniszew - kontynuują tradycję kamedulską. Liczne ograniczenia W życiu zakonników, ograniczona dostępność i, co za tym idzie, tajemniczość tych obiektów powodują dużą ciekawość i zainteresowanie wiernych tą wspólnotą. Z kolei ascetyczny sposób życia zakonników wpływa na to, że pustelnie kamedulskie uważane są za oazy religijności. Cisza i spokój panujące w obiektach i ich otoczeniu sprzyjają refleksji i zastanowieniu się nad sensem życia i śmierci.

\subsection{LOKALIZACJA KLASZTORÓW}

Potrzeba izolacji, odosobnienia powodowala, że kamedulskie założenia klasztorne lokowane były W miejscach zapewniających spokój i umożliwiających kontemplacje. Poszukiwano miejsc odludnych, położonych w cichym otoczeniu. PrawidłoWość tę potwierdza analiza polożenia polskich zeSpołów klasztornych. Większość z nich powstała Wśród lasów, na wzniesieniach lub na obszarach, w których występowały oba elementy przyrodnicze. Na szczególną uwage w omawianej grupie zasługuje klasztor w Wigrach, położony dodatkowo had jeziorem (MACIEJEWSKI 1999). O wadze, jaką przywiązywano do miejsca lokalizacji świadczą nazwy własne nadawane poszczególnym założeniom, np. Erem Srebrnej Góry, Pustelnia Złotego Lasu, Erem Wyspy Wigierskiej. only on strictly defined days of the year (12 days). The monks lead a very ascetic life they take an oath of individual and collective poverty and observe fasts which they impose on themselves. The monks' severe lifestyle is also symbolized by their appearance - long beards and shaved heads. Their everyday clothes are white habits over which they wear white scapulars with hoods.

The order worships the Virgin Mary, and this can be seen in the names of Cameldolite churches as most are devoted to Her (table I). The Marian cult was also popular in the $17^{\text {th }} \mathrm{c}$. Poland. A well-known saying among the Cameldolites is memento mori-remember death. They are to prepare for it throughout their life in the order. After they die, members of the community are buried in catacombs in the monastery premises.

Among the Polish monasteries discussed here, two - Bielany (Kraków) and Bieniszew - continue the Cameldolite tradition. The numerous restrictions on the monks' lives, their limited access and, in consequence, the mysteriousness of the monasteries arouses the curiosity of believers and interest in this community. The monks' ascetic way of living makes the Cameldolite hermitages oases of religiousness. The peace and quiet of the buildings and surroundings are conducive to reflection on the meaning of life and death.

\subsection{LOCATION OF MONASTERIES}

The need for isolation led the monks to locate their monasteries in places which guaranteed peace and made contemplation possible. They looked for secluded, peaceful sites, as the location of Polish monasteries shows. The majority were erected among forests, on hills or in areas including both these natural elements. Particular attention should be paid to the monastery in Wigry, located by a lake (MACIEJEWSKI 1999). Location was of utmost importance, as seen in the names of the monasteries, e.g. Srebna Góra (silver mountain), Złoty Las (golden forest) and Wyspa Wigry (Wigry island). 


\subsection{UKŁAD ZESPOEU KLASZTORNEGO}

Klasztory kamedulskie w Polsce budowane były zgodnie z postanowieniami Kapituly Generalnej na Górze Koronnej z 1610 r. W obrębie założenia obowiązywał podział na trzy strefy (rys. 2).

\subsection{THE MONASTERY}

The Cameldolite monasteries in Poland were built following decisions taken by the General Chapter on Monte Corona in 1610. The monastery premises are divided into three zones (fig. 2).

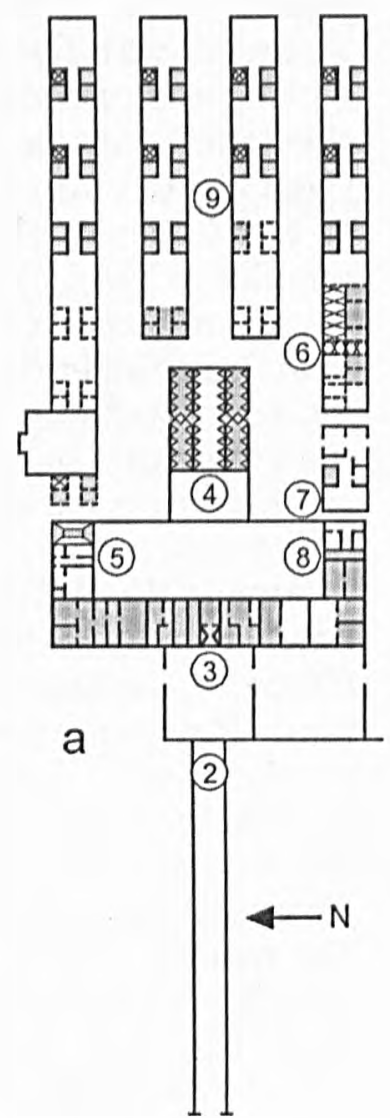

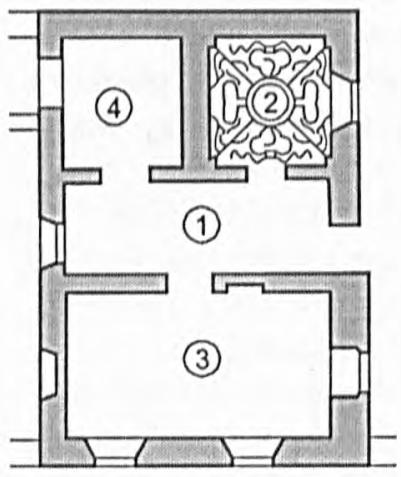

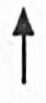

N

b

Rys. 2. Plan założenia kamedulskiego w Rytwianach wg M. Brykowskiej (Rytwiany... 2001)

a: 1-2 bramy, 3 -furta klasztorna, 4-kościół, 5-foresteria z refektarzem, 6 -domki braci konwersów i infirmeria, 7 - kuchnia ze studnia, 8 - apteka, 9 - domki pustelnicze;

b: plan domku pustelniczego: 1 - przedsionek, 2-kaplica, 3-cela, 4 -drewutnia i latryna

Fig. 2. Plan of the Cameldolite monastery in Rytwiany according to Brykowska (Rytwiany... 2001)

a: 1-2 gates, 3 - church door, 4 - church, 5-foresteria with refectory, 6 -infirmary and building

where conversation is allowed, 7 - kitchen with a well, 8 - pharmacy, 9 -hermitages;

b: plan of an individual hermitage: 1 - porch, 2 - chapel, 3-cell, 4- woodshed and lavatory

Strefa pierwsza, tzw. szyja dojazdowa, zaczynała się przy pierwszej bramie do klasztoru, a kończyła na furcie klasztornej. Na strefę drugą składały się - kościól, przylegający do niego dziedziniec oraz budynki klasztorne, np. foresteria (pomieszczenia dla gości) czy apteka. Strefę trzecią, niedostępną dla osób z zewnątrz, tworzyły cele pustelnicze (eremitoria) z ogródkami. Całe założenie ogrodzone było murem i charakteryzowało się wyraźną
The first zone begins at the main gate and finished at the wicket door of the church. The second included the church, the adjacent churchyard and monastery buildings, e.g. foresteria (guests' quarters) or the pharmacy. The third, inaccessible to people from outside, consisted of cells (eremitoria) with gardens. The premises were surrounded with a wall and showed 
symetrią. Oś podziału przechodziła przez bramy, dziedziniec, kościół oraz wzdłuż ciągów domków i ogródków eremickich. Ściśle określone przepisy dotyczyły także wyglądu kościoła (rys. 3). Świątynia miała być budowla jednonawową $z$ bocznymi kaplicami. W bezpośrednim sąsiedztwie oltarza powinny znajdować się kapitularz (miejsce spotkań kapituły) oraz zakrystia, $\mathrm{z}$ wydzieloną kaplicą i lawaterzem (miejscem do obmycia rąk). Powyższy kanon zastosowano we wszystkich pustelniach kamedulskich w Polsce, a klasztor w Rytwianach pod tym względem uważano za wzorcowy w skali europejskiej (Rytwiany ..., 2001). clear symmetry. The axis ran through the gates, the churchyard, the church and along the hermit cells and gardens. There were strict principles to follow as regards the appearance of the church (fig. 3) which was to be a one-aisle building with side chapels. Close to the altar there should be the chapter house and the sacristy with a chapel and a place to wash hands. The above canon was applied in all Cameldolite hermitages in Poland and the monastery in Rytwiany was considered exemplary on a European scale (Rytwiany..., 2001).

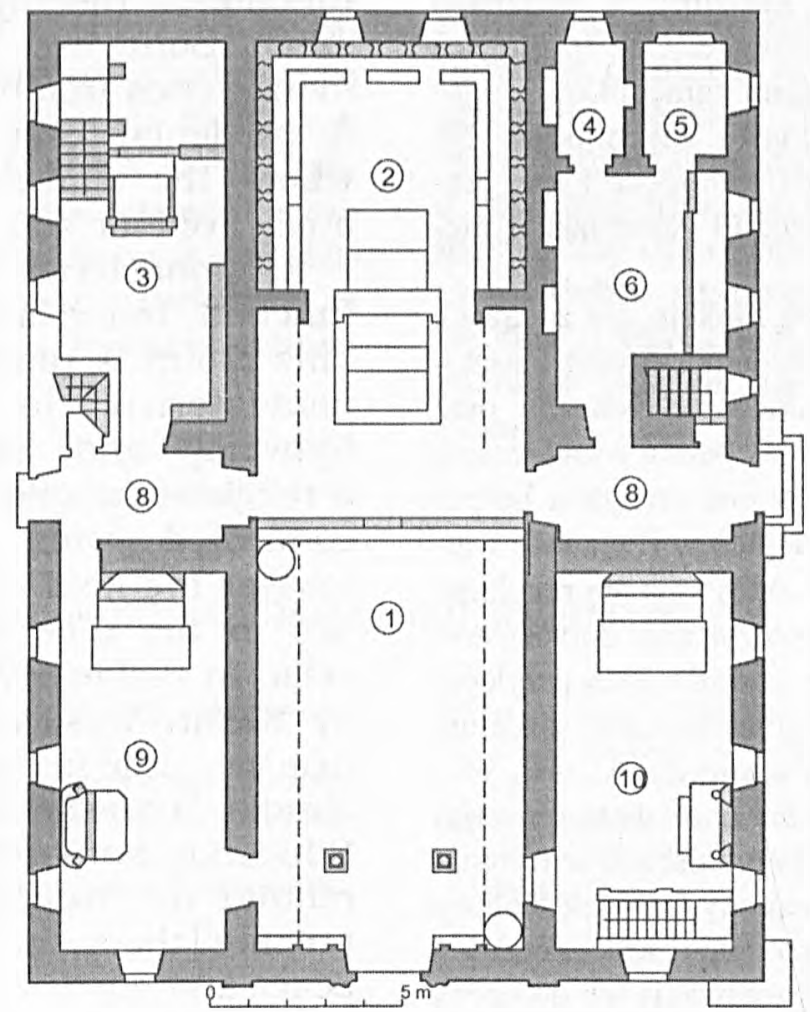

Rys. 3. Plan kościoła kamedulskiego w Rytwianach wg M. Brykowskiej (Rytwiany... 2001)

1 - chór zakonny w nawie, 2 - chór zakonny za ołtarzem, 3-kapitularz, 4 - lawaterz, 5-kaplica, 6-zakrystia, 7 - wieża zegarowa, 8-przedsionki, 9-10-kaplice

Fig. 3. Plan of the Cameldolite church in Rytwiany according to Brykowska (Rytwiany... 2001)

1 - choir in the nave, 2 - choir behind the altar, 3 - chapter house, 4 - wash room, 5 - chapel, 6 - sacristy, 7 - clock tower, 8 - porches, 9-10 - chapels

W grupie omawianych klasztorów stopień zachowania założenia jest zróżnicowany. Najlepiej zachowało się ono w krakowskich Bielanach (całe założenie), najsłabiej w Szańcu (przetrwała tylko drewniana kaplica). Pozostałe klasztory zachowały się częściowo, w każdym przypadku przetrwał jed-
The present condition of the monasteries varies. The best-preserved is the monastery in Bielany (Krakow) (the whole complex has survived) while in Szaniec only the wooden chapel has remained. Other monasteries have been partly preserved, in each case 
nak kościól. Z wyjątkiem założenia w Szańcu, w pozostalych obiektach na podstawie zachowanych fragmentów można odtworzyć (wyobrazić sobie) całość założenia.

\section{WSPÓŁCZESNE WYKORZYSTANIE OBIEKTÓW}

Kamedulskie zespoly klasztorne w obecnych granicach Polski ze względu na ich wspólczesne wykorzystanie można zakwalifikować do jednej $\mathrm{z}$ trzech grup obiektów.

1. Obiekty kontynuujące pierwotną funkcję. Do grupy tej zaliczyć należy klasztory w Bielanach krakowskich oraz w Bieniszewie. Oba te miejsca są obecnie klasztorami zakonu kamedulów, a ogólem zamieszkuje je kilkunastu zakonników. Na szczególną uwagę zasługuje zwłaszcza Erem Srebrnej Góry, w którym kameduli zamieszkują nieprzerwanie od 400 lat.

2. Obiekty pelniące nową funkcję, ale związaną z pierwotna. Grupę tę reprezentują dawne klasztory w Bielanach warszawskich, Rytwianach oraz w Szańcu. Wymienione obiekty pełnią współcześnie funkcję religijna, ale nie jest ona związana bezpośrednio z zakonem. W kościołach w Bielanach warszawskich oraz Rytwianach odbywają się regularne nabożeństwa, różnica w wykorzystaniu dotyczy eremów. W przypadku Bielan warszawskich przylegające do świątyni częściowo zachowane pustelnie wykorzystywane są przez Uniwersytet Stefana Wyszyńskiego, który ulokował się obok dawnego założenia klasztornego. Z kolei przy kościele w Rytwianach powołany został Diecezjalny Ośrodek Kultury i Edukacji „Źródło”, którego celem jest odbudowa zniszczonych eremów i przygotowanie ich do pobytu osób szukających ciszy i spokoju.

3. Obiekty pelniące nową funkcję. Przykładem obiektu, który realizuje nową funkcję jest dawny klasztor kamedulski w Wigrach. Wprawdzie kościól jest nadal obiektem sakralnym, ale odbudowane eremy pelnią współcześnie funkcję noclegową jako Dom Pracy Twórczej Ministerstwa Kultury i Dziedzictwa Narodowego.

\section{ZAKOŃCZENIE}

Dziedzictwo kulturowe zakonu kamedułów w Polsce wyraża się zarówno w aspekcie materialnym, jak i duchowym. Prezentowane polskie założe- however the church has remained. With the exception of Szaniec, it is possible to recreate the original buildings on the basis of the preserved fragments.

\section{CONTEMPORARY USE OF MONASTERY BUILDINGS}

According to how they are currently used, Cameldolite monasteries within contemporary Polish borders belong to one of three groups:

1. Monasteries that continue the original function - Bielany (Kraków) and Bieniszew. Both are currently Cameldolite monasteries inhabited by several monks. A particular case is the Srebna Gora where the Cameldolites have continuously lived for 400 years.

2. Monasteries which perform a new function, but related to the original one. This group is represented by the former monasteries in Bielany (Warsaw), Rytwiany and Szaniec. They perform a religious function but it is not directly connected with the order. Regular masses are held in them and the change lies in the different use of the hermit cells. In Bielany (Warsaw), they are used by Stefan Wyszyñski University located nearby, while in the Rytwiany church the 'Źrodło' Diocesan Centre for Culture and Education has been located. Its aim is to rebuild the ruined hermit cells and to prepare them for people searching for peace and quiet.

3. Monasteries which perform new functions, for example that in Wigry. Although the church is still a consecrated building, the rebuilt hermit cells function as accommodation (Dom Pracy Twórczej a retreat for writers and artists, part of the Ministry of Culture and National Heritage).

\section{CONCLUSIONS}

The cultural heritage of the Cameldolite order in Poland can be viewed both in its material and spiritual aspects. The mon- 
nia klasztorne wpisują się w określoną koncepcję przestrzenną wypracowana przez zakon, a dotyczącą miejsca lokalizacji i wyglądu zespołu. Każdy $\mathrm{z}$ opisywanych obiektów ze względu na czas powstania ma określoną wartość historyczną oraz artystyczną, wyrażającą się poprzez styl architektoniczny, dekoracje wnętrz czy wyposażenie. Zachowane w różnym stopniu założenia klasztorne są dowodem obecności kamedulów na ziemiach polskich, ilustracją ich historii, ale także świadectwem wiary spoleczeństwa polskiego. Spuściźnie pozostawionej przez zakon współczesna historia dopisuje kolejną kartę. W przypadku Bielan krakowskich i Bieniszewa można mówić o trwałości tradycji kamedulskiej, wyrażającej się w obecności zakonników i w przestrzeganiu zasad życia i obyczajów panujących w zakonie, co niewątpliwie nadaje tym miejscom specyficzną atmosferę. Pozostałe obiekty pelnią funkcję religijną bądź realizują nowe. Bez względu jednak na współczesne wykorzystanie dawnych kamedulskich założeń klasztornych można stwierdzić, że zakon na stałe wpisal się w krajobraz kulturowy Polski. asteries presented above follow a particular spatial concept established by the order as regards location and construction. As they were built many years ago, each monastery has historical and artistic value expressed in the architectural style, interior design and facilities. The monasteries are proof of Cameldolite presence in Poland, an illustration of their history, but also evidence of religious faith in Polish society. The contemporary period adds to the heritage left by the order. In the case of Bielany (Kraków) and Bieniszew, we can talk about the stability of the Cameldolite tradition, reflected in the presence of monks who continue to follow the principles and customs of the order. This surely gives the places a special atmosphere. The remaining monasteries either still perform a religious function or a new one. Regardless of the contemporary use of the former Cameldolite monasteries, however, it can be stated that the order has become a permanent part of the cultural landscape of Poland.

\section{BIBLIOGRAFIA - BIBLIOGRAPHY}

FLoRKowscy M., M., 2005, Kameduli, Wydawnictwo M, Kraków.

ŁozIŃSKI B., 2002, Leksykon zakonów w Polsce. Instytuty życia konsekrowanego $i$ stowarzyszenia życia apostolskiego, Katolicka Agencja Informacyjna.

MACIEJEWSKI S., 1999, Opowieść o kamedutach wigierskich, Oficyna Żak, Suwałki.
PRUSZYŃSKI J., 2004, Spotkania w Willi Struvego 20012003. Wyktady o dziedzictwie kultury. Towarzystwo Opieki nad Zabytkami, Warszawa.

Rytwiany. Pustelnia kamedulska. Przewodnik po zabytkach sztuki, 2001, nr 16, Wydawnictwo ABC, Tarnobrzeg. 